\title{
MAINSTREAMING ISLAMIC JURISTIC THOUGHT IN THE TEACHING OF HUMAN RIGHTS LAW: A CASE FOR INTEGRATIVE CURRICULUM AND PEDAGOGY IN AFRICAN LAW SCHOOLS
}

\author{
'Dejo Olowu* \\ LLB(Hons) LLM PGDip JSD \\ Barrister and Solicitor (Nigeria) \\ Research Professor of Law, North-West University \\ (Mafikeng Campus)
}

\section{SUMMARY}

Against the backdrop of the marked marginalization of Islamic juristic thought in human rights discourses and the consequential obscurity of possible synergy, this article proceeds from the premise that purposeful human rights education within a law degree programme leading to vocational careers must be all encompassing, able to respond to the demands of critical reasoning, and suitable for the analysis and understanding of global, regional and national challenges by local legal actors. In the African context, experience evokes an appeal for innovative approaches that not only prioritize integrative curricula but which also facilitate qualitative teaching methods that could guarantee the transfer of helpful skills and broad-based knowledge to boost the confidence of the learner in visualizing active future roles in human rights promotion and protection in whichever milieu he/she establishes a career. Highlighting the peculiar importance of Islamic Law in twenty-first century Africa, this article canvasses an approach that helps the law student to understand the practical realities that make Islamic Law a sine qua non for sound grasp of human rights law in his or her society while fully recognizing latent cultural, religious and other philosophical dilemmas and limitations to human rights as legal norms.

\section{INTRODUCTION}

Much like Christianity, Islam is a non-indigenous proselytizing religion introduced to Africa through contacts with Arab merchants. Since the seventh century when Islam was introduced to Northern Africa, it has recorded unmistakable spread across the Sahara Desert with notable

The author is grateful to Professor Camille Kuyu of the Institut Universitaire André Ryckmans and Professor Sam Amoo of the University of Namibia, for their support. E-mail: djolowu1@yahoo.co.uk. 
incursions into West and Eastern Africa. ${ }^{1}$ The spread of Islam is far from waning in Africa and the presence of Muslims (adherents of Islam) is becoming notable in countries of Southern Africa, particularly South Africa. ${ }^{2}$

Simultaneously introduced to Africa alongside Islam was Islamic law, otherwise known as Sharia as well as the Arabic language. For Muslims, observing the Sharia is not merely ritualistic, but is an expression of submission to, and love for, God. The legal dimension of Sharia gives Islam its form while the spiritual dimension is its substance. ${ }^{3}$

While various scholars and commentators have examined Sharia in many works, research has largely not been able to avoid the suspicions, pitfalls and mistrusts permeating the ranks of scholars who interpret the norms and practices in other proselytizing religions to suit their personal worldviews and interests. ${ }^{4}$ In my view, the sensitivity of religious discourses should not become a bulwark against critical engagement with the elements of any religion where such could enhance the life, freedom and dignity of human beings anywhere. In the context of this article, I consider that researching and teaching the contents of the Sharia which have implications in the delivery of the human rights component of legal education will only strengthen the capacity of legal professionals to deal with current dilemmas and future legal challenges in the human society.

\section{ISLAMIC LAW AND LEGAL EDUCATION IN THE AGE OF GLOBALIZATION}

Arguably, one of the notable hallmarks of present-day globalization has been its remarkable influence on legal education and legal education curricula around the world. Whereas it would have been unthinkable three decades ago to find an Islamic Law module in the legal education curriculum of universities located in countries traditionally perceived as "Western" and

\footnotetext{
See Westerlund and Rosander African Islam and Islam in Africa: Encounters Between Sufis and Islamists (1997); Esterhuysen Africa A-Z: Continental and Country Profiles (1998) 21; Levtzion and Pouwels The History of Islam in Africa (2000); and Doi "Islam and Africa" $<$ http://members.tripod.com/worldupdates/islamintheworld/id25.htm> (accessed 2010-0214).

2 See generally Tayob Islam in South Africa: Mosques, Imams and Sermons (1999); Mahida "History of Muslims in South Africa" <http://www.sahistory.org.za/pages/libraryresources/online\%20books/history-muslims/1600s.htm> (accessed 2010-02-14); Latif "Islam in South Africa" <http://www.themodernreligion.com/convert/southafrica.html> (accessed 2010-02-14)

3 See An-Na'im "Islamic Law and Human Rights Today" 199610 Interights 3; Wiechman, Kendall and Azarian "Islamic Law: Myths and Realities" <http://www.acsp.uic.edu/oicj/ pubs/cji/120313.htm> (accessed 2010-02-14).

4 See generally Renteln International Human Rights: Universalism Versus Relativism (1990) 69; Falk "Cultural Foundations for the International Protection of Human Rights" in An-Na'im (ed) Human Rights in Cross-Cultural Perspectives (1992) 54; Cooper Value Pluralism and Ethical Choice (1993); Kamal and Mahmod "The Importance of Understanding and Teaching Islamic Law in Asia" 2006 1(1) Asian Journal of Comparative Law 14 Contributions from various scholars to an online discussion forum launched in 1995 on Islamic Law in Africa give further insight into this scenario. See "African Islamic History" <http://www.h-net.org/ africa/threads/islamthread.html> (accessed 2010-02-14).
} 
"Christian" strongholds, a new trend is emerging showing a growing but steady culture of embrace for Islamic law or the integration of aspects of Islamic law in legal education curricula. As a pointer, various universities in countries such as Australia, Austria, Belgium, the Netherlands, New Zealand, Norway, the United Kingdom, the United States, among others, now run modules either incorporating aspects of Islamic Law or Islamic Law stand-alone modules. ${ }^{5}$ In some Western universities, Islamic law is sometimes taught by faculties and departments specializing in MiddleEastern and Oriental studies. For example, Islamic Law is offered as a major in the School of Oriental and African Studies (SOAS) of the University of London. Harvard Law School also offers Islamic Law as an elective course. ${ }^{6}$ These are just a few examples of the widespread teaching of Islamic law worldwide, and it is worthy to note here that Islamic Law is becoming an important field for graduate research degrees in many leading universities around the world. Some universities in Western countries are even establishing themselves as icons of Islamic legal studies. ${ }^{7}$ Strengthening this growing trend of embrace is the wealth of scholarship and outlets for Islamic law research in Western countries. ${ }^{8}$ One could safely ascribe this spate of integration to the end of the Cold War, the tremendous increase in human migration across vast borders and the unmistakable influence of new age information technology. ${ }^{9}$

In the preponderance of African countries, as in most other countries of the world, the basic requirement for a career in the legal profession is the possession of a Bachelor of Laws (LLB) degree or its equivalent in other countries. Expectedly, this degree is ordinarily obtainable after a mandatory period of study in a recognized university.

5 See, eg, LAW 549 - Seminar: Islamic Law and Human Rights, offered at the University of California, Los Angeles <http://www.law.ucla.edu/home/index.asp?page=331> (accessed 2010-02-14); ET 640 - Introduction to Islamic Law, offered at the Hartford Seminary <http://www.hartsem.edu/ACADEMIC/coursedescrip.htm> (accessed 2010-02-14); and see also Armini "Brave New Courses: Harvard Law Curriculum Expands to Meet a Changing World" <http://www.law.harvard.edu/news/today/2002/03/1courses.php> (accessed 201002-14).

6 In Harvard Law School, Islamic Legal System is an elective course in the JD programme, apart from an Islamic Law Studies Programme. See <http://www.law.harvard.edu/ programs/ilsp/> (accessed 2010-02-14). At the SOAS, Islamic Law is an elective subject for its LLB programme as well. See <http://www.soas.ac.uk/academics/centres/cimel/> (accessed 2010-02-14).

7 A vivid example here is the Islamic University of Rotterdam, in the Netherlands. See "Islamic University of Rotterdam", <http://www.islamicuniversity.nl/en/showcontent.asp? $\mathrm{id}=105>$ (accessed 2010-02-14). Others include the University of Warwick and the Brunel University, in the United Kingdom as well as Emory University in the United States.

8 Examples of periodicals with special focus on Islamic Law would include Journal of Islamic Law and Culture; UCLA Journal of Islamic and Near Eastern Law; Yearbook of Islamic and Middle Eastern Law; Journal of Islamic Studies, Islamic Law and Society, and so on. For a compilation of various programmes and resources on Islamic Law in the Western world, see Grossman "Finding the Law: Islamic Law (Sharia)" <http://www.Ilrx.com/features/islamiclaw. htm> (accessed 2010-02-14).

$9 \quad$ See Blake "Teaching Islamic Civilization with Information Technology" 1998 The Journal for MultiMedia History 1 available at <http://www.albany.edu/jmmh/vol1no1/teach-islamic.html> (accessed 2010-02-14). 
The focus of this article is, however, not about the legitimacy of law degrees or of the monopoly that universities enjoy in the award of law degrees. Rather, it is about the content of the curriculum leading to the award of the LLB degree. A random survey of available curricula of studies leading to the award of an LLB degree in a number of African universities providing foundational training for prospective vocational practitioners and administrators of the law reveals that many of them run their LLB programmes heavily modelled after the legal traditions of Western colonial states, to the exclusion of Islamic law. It is commonplace, therefore, to find law faculties and departments without any module on Islamic law or even any reference to the Islamic worldview about the various aspects of relevant law modules. I contend that this approach to legal education is archaic, ossifies the perceptions of prospective legal minds about social challenges and policy dilemmas; confines the learning of the law within narrow cognitive stereotypes; and also blunts opportunity for the critical enquiry necessary to provoke learners into finding solutions to manifold social and interpersonal challenges from ample moral and legal precepts.

One particular casualty of this scenario has been the marginalization of the possible and practical synergy between human rights law discourses and Islamic juristic thought. Qualitative legal education delivery cannot afford to ignore the critical influence of Islamic law in societies where its precepts define the way its adherents perceive human rights.

This article proceeds on the premise that appropriate human rights education within a law degree programme leading to vocational careers should be all encompassing and suitable for the analysis and understanding of global, regional and national problems by local legal actors. I argue that purposeful human rights education must respond to the demands of critical reasoning and the evolution of pragmatic responses to local, regional and global challenges, tensions and conflicts. In the African context, experience evokes an appeal for innovative pedagogical approaches that not only prioritize integrative curriculum but one which also facilitates qualitative teaching methods that guarantee the transfer of helpful interdisciplinary skills and broadened knowledge that could boost the confidence of the learner in visualising active future roles in human rights promotion and protection in whichever milieu he/she establishes a career. The approach canvassed in this article brings the law student closer to the life of a conscientious human rights advocate, one who will not unnecessarily perceive human rights as a one-way platform for solving every personal and societal problem, but one who will appreciate them as a bundle of multidimensional tools for emancipating the self, for influencing policy, for advocating social and political reform, while fully recognizing the latent cultural, religious and other philosophical dilemmas and limitations to their validity as legal norms. 


\section{COLONIALISM, THE LAW AND LEGAL EDUCATION IN AFRICA: AN OVERVIEW}

While exact statistics are difficult to come by, it is generally estimated that adherents of Islam and Islamic law consist of about one-fifth of the entire population of the world. ${ }^{10}$ Although one should avoid speculating about the African component of the foregoing estimation, an empirical survey conducted in 1998 showed that Islam was the predominant religion in some fourteen African states while it was one of the two dominant religions in ten others. ${ }^{11}$ It is remarkable that in today's Africa, the increasing human movements across the continent resulting from conflicts, civil wars, natural disasters, repression, quest for livelihood, and the pressures of economic globalization, Islam is spreading to states which were hitherto regarded as overwhelmingly Christian. ${ }^{12}$

It must be remembered that apart from Ethiopia, all African states were, at one time or the other, colonies of Western powers. While the colonial powers did not outrightly abrogate the indigenous customary law or the Islamic legal system where such had been adopted prior to their arrival in Africa, it was the foreign legal system introduced by the colonial administrators that became the dominant legal system. ${ }^{13}$ The transplant of laws by the fiat of colonial overlords was to have enduring social and legal repercussions for African societies. While colonialism promoted social dislocations which have perpetually fuelled some of the present-day turmoil in many African states where societies are polarized along religious lines, for example, Chad, Nigeria, and Sudan, a new realization is emerging that Muslim dignity and identity could only be preserved through the positive recognition and entrenchment of Islamic law in societies where this system had been relegated or restricted in application. ${ }^{14}$

Islamic law plays an important role in the preservation of Muslim identity. During the colonial period, the use of Islamic law had to be negotiated on the basis of official recognition of Islamic personal and family law in many countries where the Islamic legal system had been firmly established prior to the advent of colonial powers. ${ }^{15}$ After decolonization, Muslims around the

10 See Lewis Islam: From the Prophet Muhammad to the Capture of Constantinople Vol II (1987) 224; and Jones-Pauly "Tensions Between Islamic Law and Human Rights from the Perspective of Comparative Law" August 1999 <http://www.humanrights.ch/home/upload/ pdf/0000990827_cjp_text.pdf> (accessed 2010-02-14).

11 See Esterhuysen 21.

12 See generally Mafukidze "A Discussion of Migration and Migration Patterns and Flows in Africa" in Cross, Gelderblom, Roux and Mafukidze (eds) Views on Migration in Sub-Saharan Africa (2006) 103116.

13 Elias The Nature of African Customary Law (1956) 1-8; and Kolajo Customary Law in Nigeria through the Cases (2000) ix.

14 Miles "Customary and Islamic Law and Its Development in Africa" 2006 (1) African Development Bank Law for Development Review 81.

15 Esterhuysen 22-23; An-Na'im 199610 Interights 4; and see also Bojonegoro Islamic Law and Social Change: A Comparative Study of the Institutionalisation and Codification of Islamic Family Law in the Nation States Egypt and Indonesia 1950-1945 (Unpublished PhD Thesis, University of Hamburg, 2005) 21-22. 
world continued to assert their identity by upholding and preserving Islamic law. The use of Islamic law has now become the symbol of legitimacy par excellence in the quest for political support of Islamic worldview. ${ }^{16}$

This is the context in which one must conceptualize the teaching of Islamic law in educational institutions, especially at the tertiary level. Many universities around the world now offer Islamic Law as a subject in their law programmes while many others have it as a distinct discipline leading to the award of distinct degrees. Many universities in Africa offer degrees in Islamic Law, or degrees that combine Islamic Law with Arabic Studies, or Islamic Law with Common Law, Islamic Law with other disciplines like Economics, Political Science, Sociology, Psychology and Communication. Of course, the contents of these programmes vary from a general introduction to more specialized modules like Islamic Family Law, Islamic Criminal Law, Islamic Commercial Transactions, and Islamic Banking and Finance Law. ${ }^{7}$

To a large extent, Islamic law features prominently in the law programmes run by universities in Northern Africa which are generally regarded as traditional strongholds of Islam as well as those in Burkina Faso, Chad, Comoros, Niger, Senegal, Somalia, and Tanzania, south of the Sahara, to mention a few. ${ }^{18}$ However, the same cannot be spoken of the law faculties in Nigeria, Cameroon, Kenya, Sierra Leone and South Africa, all of which have considerable Muslim populations. While law faculties located in northern Nigeria have Islamic law in prominent profile as found in northern African states, ${ }^{19}$ the law faculties located in southern Nigeria and southern Cameroon either have it as a portion in a module or not at all. In South Africa, no law faculty offers a degree programme specifically designed for Islamic law, and in the majority of South African law faculties, the subject even fails to record a mention as a distinct module. ${ }^{20}$ This same scenario plays out in law faculties located in numerous countries of Central, Eastern and Southern Africa, including Angola, Botswana, Congo Brazzaville, Ethiopia, Kenya, Lesotho, Malawi, Mozambique, Rwanda, Swaziland and Zimbabwe.

16 An-Na'im 199610 Interights 4; Afshari "An Essay on Islamic Cultural Relativism in the Discourse on Human Rights" 199416 Human Rights Quarterly 235 237-239; and Yilmaz Muslim Laws, Politics and Society in Modern Nation States: Dynamic Legal Pluralisms in England, Turkey and Pakistan (2005).

17 See generally Cardinal "Islamic Legal Theory Curriculum: Are the Classics Taught Today?" 2005 12(2) Islamic Law \& Society 224.

18 See Gesink "Islamic Reformation: A History of 'Madrasa' Reform and Legal Change in Egypt" 2006 50(30) Comparative Education Review 325-345; and Zanzibar University "Faculty of Law and Sharia" <http://www.zanvarsity.ac.tz/FacultyLaw.html> (accessed 201002-14).

19 See, eg, Yahaya Constitutional Foundation of a Sharia Legal System in Nigeria (2001); and Umar "Education and Islamic Trends in Northern Nigeria: 1970s-1990s" 2001 48(2) Africa Today 126-150.

20 For fuller insight into the state of Islamic Law in legal education in South Africa, see Abdullah "Towards the Development of Teaching Islamic Canon Law at the University of the Western Cape: Some Suggestions for Designing A Comparative Legal Curriculum for Undergraduate LLB Students in South Africa" 2006 4(2) Journal of Commonwealth Law \& Legal Education 187-194. 
If the foregoing broadly describes the place of Islamic law in the framework of legal education in Africa, it becomes logical to visualize the absence of Islamic Law dimension in human rights modules in African law faculties. The perception that Islamic Law is asymmetrical to human rights is paradigmatic of law schools and their handlers in our West-oriented world. ${ }^{21}$

At the dawn of the 21st century, however, in light of the events before and particularly in the aftermath of the 11 September 2001 terrorist attacks on strategic US structures, and widespread abuses of the dignity of human beings in diverse countries, universalistic scholars in numerous Western countries have taken interest in enquiring into and identifying the human rights dimensions of Islamic law in increasing measures. ${ }^{22}$ While it serves no purpose to revisit the wealth of literature on the growing integration of Islamic juristic thought into the teaching of human rights in faraway countries, the point here is to underscore the significance of this growing practice for human rights teaching and research in Africa, in an analytical way.

\section{GLOBAL HUMAN RIGHTS DISCOURSE: INTERROGATING MISCONCEPTIONS ABOUT ISLAMIC LAW}

Islamic law is commonly misunderstood especially Islamic penal law which is often associated with punishments like amputation for stealing, stoning for fornication, and decapitation for drug-trafficking. Media coverage of such events as public executions in Saudi Arabia; hadi lashing (caning in public) for alcohol consumption in Pakistan; or for fornication in Indonesia; and death sentence for fornication in Northern Nigeria has aided the growing perception of Islamic law as a legal system whose tenets are obsolete and cruel. ${ }^{23}$ It will be erroneous for anyone to judge the character of a complex social, spiritual and legal system as Islam without proper grasp of its rich origins and history, because in these lie the very basis of the ubiquitous misunderstanding of a pious faith and system. To understand Islamic law, therefore, one must first understand the assumptions of Islam and the basic tenets of the religion.

21 See Said "Human Rights in Islamic Perspectives" in Pollis and Schwab (eds) Human Rights: Cultural and Ideological Perspectives (1979) 63-80; Heinemeijer "Islam and the Ideals of the Enlightenment" in Berting, Baehr, Burgers, Flinterman, De Klerk, Kroes, Van Minnen and VanderWal (eds) Human Rights in a Pluralist World: Individuals and Collectivities (1990) 145; Aka and Browne "Education, Human Rights, and the Post-Cold War Era" 199915 New York Law School Journal of Human Rights 421; and Douglass and Dunn "Islam: Enduring Myths and Changing Realities - Interpreting Islam in American Schools" 2003588 Annals 52 .

22 See Backer "Human Rights and Legal Education in the Western Hemisphere: Legal Parochialism and Hollow Universalism" 200221 Penn State International Law Review 115; and Harris-Short "International Human Rights Law: Imperialist, Inept and Ineffective? Cultural Relativism and the UN Convention on the Rights of the Child" 2003 25(1) Human Rights Quarterly 130.

23 See Smock Applying Islamic Principles in the Twenty-First Century: Nigeria, Iran, and Indonesia United States Institute of Peace, Special Report No 150 (2005) 2-9. 
Islamic law or Sharia in Arabic means the clear and well-trodden "the way to the place of water". ${ }^{24}$ Contextually, the Sharia is that immutable law laid down by Allah (that is, God, in English transliteration) for human beings, and just as water is vital to human life, the Sharia, with its lucidity and candour, is the means of sustaining human souls and minds. ${ }^{25}$ For Muslims, therefore, the Sharia regulates all human actions and covers every aspect of human life. It includes laws relating to personal acts of worship, laws on commercial transactions, personal law matters and penal laws. ${ }^{26}$ The Sharia is based on divine wisdom, and thus man-made laws must be in conformity with the Qur'an and Sunna (the authoritative source of the Prophet's deeds and sayings). To be a Muslim is therefore tantamount to accepting the Sharia, and invariably the injunctions of $A l l a h^{27}$

Because of the chequered history of Islam as a spiritual way of life, as a jurisprudential system, and as a social order, its precepts have been the subject of divergent latitudes of interpretation. Following the death of the Prophet Muhammad, various Muslim schools of thought emerged whose followers greatly differed among themselves, leading to the formation of other parallel schools of thought. ${ }^{28}$ In the eighth century, for instance, a difference in legal approach arose amongst Islamic thinkers in two popular schools of thought. The traditionalists (ahl al-hadith) relied only on the Qur'an and the Sunna as the only valid sources for jurisprudence, such as the prevailing thought emanating from Medina. The non-traditional approach (ahl al-ra'y), which was heralded in Iraq, relied on the free use of logic and opinion in the absence of reliable hadith. ${ }^{29}$ The reason for the difference in technique is that in Medina, there was an abundance of reliable hadith that scholars could depend on for forming legislation, since the Prophet lived the last ten years of his life in that young Muslim community. ${ }^{30}$ In Iraq the sources that were available were not as reliable as in Medina and consequently the jurists had to turn to analogy because of their circumstances. It follows, therefore, that a hadith may have been accepted by Malik (from Medina) and not by Abu Hanifa (from Iraq) who had to use analogy in the absence of reliable hadith. A challenge that jurists had to reconcile was which of the Prophet's actions and decisions were religiously binding and which were merely a function of personal discretion of the Prophet. In general, ahl al-hadith ultimately lent legislative importance to

24 Kamali Principles of Islamic Jurisprudence (2005) 4.

$25 \mathrm{Ibid}$; and see also Said 63-80; and Rabbani "Sharia: The Clear Path" <http://www. Islamionline.net/livedialogue/english/browse.asp?hGuest> (accessed 2010-02-14).

26 Ibid.

27 See Morgan-Foster "Third Generation Rights: What Islamic Law Can Teach the International Human Rights Movement" 2005 Yale Human Rights \& Development Law Journal 6782.

28 Hallaq "The Origins and Evolution of Islamic Law" 2008 19(1) Journal of Islamic Studies 109.

29 See generally Douglass and Dunn 2003588 Annals 61-65; and Arzt "The Application of International Human Rights Law in Islamic States" 1990 12(2) Human Rights Quarterly 202 204.

30 Douglass and Dunn 2003588 Annals 64; and see also Hoover "Perpetual Creativity in the Perfection of God: Ibn Taymiyya's Hadith Commentary on God's Creation of this World" 2004 15(3) Journal of Islamic Studies 287-329. 
much of the Prophet's decisions, whereas other schools tended to distinguish between the various roles that the Prophet played in his lifetime. ${ }^{31}$

Worried about the variety of doctrines and sources of Islamic law, Muhammad ibn Idris al-Shafi'i attempted to establish a common methodology for all schools of Islamic law. His efforts resulted in the systemization of usul al-figh, the four main sources of Islamic law: the Qur'an; the Sunna (the traditions of the Prophet Muhammad); the ljma' (scholarly consensus); and the Qiyahs (legal analogies). ${ }^{32}$

The Qur'an - that sacred document revealed to Prophet Muhammad over a period of 23 years - contains both spiritual and dogmatic principles to establish the oneness of God and to deal with human relations and human behaviour. The Qur'an is the main source of legal rules of the Sharia. It provides, for example, for the general rules of civil transactions, the codes of civil and criminal evidence, the rules governing marriage and divorce. The Qur'an also provides for definitive penalties for crimes which threaten state security, some crimes requiring fixed penalties and other crimes for which there is discretion. ${ }^{33}$ The Sunna, commonly referred to as the Hadith, refer to the words and acts of Prophet Muhammad which exemplify the right interpretation of Qur'anic injunctions. The ljma' and Qiyahs are sources of law that originate from the opinion of the scholars (ulema). ljma' or scholarly consensus is reached through consultative efforts or juristic reasoning known as collective ijtihad. It usually contains legal rulings on matters that are not clear according to the Qur'an and Sunna. When established through scholarly consensus, these rulings are decisively authoritative. ${ }^{34}$ This is necessary to prevent a multiplicity of interpretations. Qiyahs or legal analogy is a powerful tool to derive rulings for matters not clearly expounded by the Qur'an, Sunna or ljma'. A good example is the prohibition on the abuse of drugs. Unlike alcohol, the Qur'an and Sunna make no reference to the abuse of drugs. However, the basis of the legal analogy is the intoxicating and destructive effect of drugs which is like the consequences of consuming alcohol. Legal analogy and its various tools enable jurists to understand the underlying reasons and causes for the rulings of the Qur'an and Sunna. ${ }^{35}$ This assists in dealing with the peculiarities and ever-changing human and environmental situations in a more consistent and structured manner.

Although to Muslims the Qur'an and Sunna are unchangeable, and there is no possibility of amending the law to meet the changing needs of society. ${ }^{36}$ However, not all aspects of the methodology of interpretation were unanimously agreed upon, the Qur'an has been variously interpreted, some

31 See Khan Human Rights in the Muslim World: Fundamentalism, Constitutionalism, and International Politics (2003) 154.

32 An-Na'im Toward an Islamic Reformation: Civil Liberties, Human Rights and International Law (1990) Chapter 2.

33 Khan 444; and Bojonegoro 31.

34 Rabbani in fn 25 above.

35 Ibid; and An-Na'im in fn 32 above Chapter 2.

36 See Ibrahim "Superiority of the Islamic System of Justice" 19944 International Islamic University Law Journal 13. 
traditions of the Prophet have been questioned for their authenticity and the extent to which they were normative imperatives, the use of analogies has been subject of debate and there is little unanimity among scholars in Islamic history about inexplicit issues. ${ }^{37}$ Without doubt, the interpretation of Islamic law precepts has always been a challenge to Muslims across the globe and will most likely remain so.

Islamic law is indeed scattered over various sources, and because of this, it is said to be uncertain, unpredictable, defective, aberrant and backward. ${ }^{38}$ These are all wrong notions. In the West scholars and commentators continue to provide vital input about Islamic law and it has become an important academic discipline in reputable institutions of higher learning. Of course, many Western scholars provide critical and often unrealistic commentaries about Islamic law. In turn, there are scholars who write in reply to such criticisms, and the debate thus goes on. ${ }^{39}$ As Weiss argues:

"Although the law [Sharia] is of divine provenance, the actual construction of the law is a human activity, and its results represent the law of God as humanly understood. Since the law does not descend from heaven readymade, it is the human understanding of the law - the human figh [understanding] - that must be normative for society."

It must be restated here, therefore, that Islamic Law is not only about polygamous marriages, the amputation of hands, and death by stoning. Islamic law does not merely deal with issues of family or personal law. For example, there is now significant interest in the advancement of Islamic banking and financial systems, and the normativization of the human rights ideals of Islamic worldview, areas which demonstrate remarkable developments in Islamic law. ${ }^{41}$ It must be stressed that the foundation of the Sharia is wisdom and safeguarding of the people's interests in this world and the next. In its entirety, Islamic Law is about justice, mercy and wisdom. As such, every tenet which sacrifices justice to tyranny, mercy to its opposite, good to evil, and wisdom to triviality, does not belong to the Sharia. The Sharia is God's justice and blessing to His people. Life, nutrition, medicine, light, recuperation and virtue are made possible by it. ${ }^{42}$

A scrutiny of the corpus of Sharia rules developed by early jurists would reveal three imperatives that have eluded contemporary critics of Sharia. One, that Sharia rules concerning particular issues have changed over time, pursuant to changes in the social and political structures of Muslim societies. Next, that jurists have adopted varying positions regarding women's and non-Muslim rights. These positions were influenced by the cultural milieu of

37 See generally Modirzadeh "Taking Islamic Law Seriously: INGOs and the Battle for Muslim Hearts and Minds" 200619 Harvard Human Rights Journal 191 206-209.

38 See generally Esposito The Islamic Threat: Myth or Reality? (1992).

39 See for instance writings of Schacht Introduction to Islamic Law (1964); Mayer Islam and Human Rights: Tradition and Politics (1991); and cf Said Orientalism (1978); and Esposito 45

40 Weiss The Sprit of Islamic Law (1988) 116.

41 See generally Modirzadeh 200619 Harvard Human Rights Journal 206-209; Jones-Pauly in fn 10 above.

42 Ibrahim 19944 International Islamic University Law Journal 31. 
the jurist, and the jurisprudential school to which he belonged. Finally, that while the systems of rights developed by orthodox Muslim jurists were far being perfect, it is evident that orthodox jurists recognized the intrinsic dignity of non-Muslims and women, even when they failed to provide a complete and comprehensive list of rights for protection. ${ }^{43}$

This is where Islamic law makes its entry point in the global human rights discourse. Contrary to the widespread idea that human rights have no place in Islamic juristic thinking, Muslims recognize that human rights emanate from God and no individual or legislative assembly has the right to alter, change, or withdraw them. ${ }^{44}$ Every Muslim or administrator who claims to be Muslim is thus obliged to accept, recognize and enforce these rights. All those temporal authorities who claim to be Muslims yet violate the rights allowed by Allah are, therefore, either unbelievers or wrong-doers. ${ }^{45}$ From the totality of the jurisprudence arising out of the four established sources of Islamic law, certain basic human rights exist for all people, Muslims and nonMuslims alike, regardless of their race, nationality, ethnic origin or language.

The first of these rights is the right to live and respect human life. Only a proper and competent court of law can decide to take a life in retaliation for murder or for punishment for spreading corruption on the earth. Only a properly established government can decide to wage war. No human being has the right by himself to take a human life for retaliation or for causing mischief on the earth. ${ }^{46}$ Further, every human has the right to the safety of life. This also means that if someone is ill, wounded, starving, or drowning, and the like, he or she has the right to be saved. ${ }^{47}$

With respect to the rights of women, Islamic law grants every woman the right to have her chastity respected and protected under all circumstances. Even in war a woman who is of the enemy nation cannot be violated. ${ }^{48}$ All promiscuous relationships are forbidden to a Muslim, irrespective of the

43 On these points, see Douglass and Dunn 2003588 Annals 64-65; and Khan "Islamic Human Rights: Islamic Law and International Human Rights Standards" 19995 Appeal: Review of Current Law and Law Reform 74 83-84.

44 See Farrag "Human Rights and Liberties in Islam" in Berling, Baehr et al (eds) Human Rights in a Pluralist World: Individuals and Collectivities (1990) 133 134; and An-Na'im "International Human Rights and Islamic Law" 2004 15(2) European Journal of International Law 400.

45 Farrag 135. In unequivocal terms, the Qur'an proclaims "Surely we have accorded dignity to the sons of Adam". See Qur'an 17: 7.

46 Farrag 137. See also Godlas "Jihad, War, Terrorism, and Peace in Islam" <http://www.uga. edu/islam/jihad.html> (accessed 2010-02-14).

47 According to Allamah Abu al-'A'la Mawdudi, Islam lays down rights for man as a human being, whether he is a believer or unbeliever. The learned author wrote that human rights in Islam include the right to life, quoting this verse of the Qur'an: "Whosoever kills a human being [except as punishment for] manslaughter, or corruption on earth, it is as though he [has] killed all mankind ..." See Mawdudi "Human Rights in Islam" 4(3) al Tawhid Journal Rajab-Ramadhan 1407 <http://www.iiu.edu.my/deed/articles/hr/hr.html> (accessed 201002-14).

48 See Baden The Position of Women in Islamic Countries: Possibilities, Constraints and Strategies for Change, Report Prepared for the Special Programme WID, Netherlands Ministry of Foreign Affairs, September 1992, 4-6, 29; and see also Mawdudi in fn 47 above Chapter 4. 
status or position of the woman, and whether or not she is a willing partner to the act. ${ }^{49}$ All people have the right to a basic standard of life. Anyone who is suffering from deprivation has a right in the property and wealth of other Muslims. ${ }^{50}$

Islamic law grants the individual the right to personal liberty. It is categorically forbidden to capture a free person and make him a slave or sell him into slavery. ${ }^{51}$ Islamic law also recognizes absolute equality among human beings. There is no superiority of Arab over non-Arab, white over black, or vice-versa. All people are descended from Adam and are therefore brothers and sisters. ${ }^{52}$ Islamic law also prescribes the general principle of the right to participate in the affairs of the state. ${ }^{53}$

These are general human rights that Islamic law gives to all. There are other rights prescribed in Islamic law dealing with issues such as the rights of enemies during times of war; ${ }^{54}$ the right to freedom of association, of expression and of conscience and conviction; ${ }^{55}$ the rights of children and even the unborn child. ${ }^{56}$

Admittedly, seeming conflicts do emerge between the Islamic legal framework for human rights and the processes of shaping the institutions of governance in Islamic societies. Far from being a manifestation of Islamic negation of human rights, such conflicts usually mirror the ideological divergence among the custodians and promoters of these institutions. ${ }^{57}$

Since international human rights norms achieve maximal effect when they garner the consent and support of national governments, it becomes critical that rather than estranging Islam and Islamic dimensions to human rights, local constituencies of advocates will need to be created to motivate and mobilize states to support and synchronize their policies and laws with global human rights norms. When international human rights become subjects of national discourses and politics, they are likely to earn local legitimacy that would crystallize into official positive action by otherwise recalcitrant

49 See Arzt 1990 12(2) Human Rights Quarterly 208; Schooley "Cultural Sovereignty, Islam, And Human Rights - Toward A Communitarian Revision" 199425 Cumberland Law Review 651 699-700; and Atiyeh, Kadry, Hayek and Musharafieh "Aesthetic Surgery and Religion: Islamic Law Perspective" 2008 32(1) Aesthetic Plastic Surgery 1432.

50 See Qur'an, 51:19; and see also Farrag 139.

51 The Qur'an lays down the following injunctions: "Do not let your hatred of a people incite you to aggression" (5:2); "And do not let your ill-will towards any folk incite you so that you swerve from dealing justly. Be just; that is nearest to heedfulness" $(5: 8)$. For further insight, see Mawdudi in fn 47 above; and Farrag 138.

52 The Qur'an 49:13 states: "And we set you up as nations and tribes so that you may be able to recognise each other." See also Dzuhayatin "Mainstreaming Human Rights in the Curriculum of the Faculty of Islamic Law" 20052 Muslim World Journal of Human Rights 1 13.

53 Qur'an 42: 38.

54 Mawdudi in fn 47 above; Arzt 1990 12(2) Human Rights Quarterly 210-211.

55 Dzuhayatin 20052 Muslim World Journal of Human Rights 12 and 13.

56 For an extensive discussion on this point, see Olowu "Children's Rights, International Human Rights and the Promise of Islamic Legal Theory" 2008 12(2) Law, Democracy \& Development 62-85.

57 An-Na'im 199610 Interights 4. 
regimes. This is one core reason why the incorporation of Islamic human rights ethos into the teaching of prospective legal practitioners - a significant constituency of local actors - becomes an imperative.

\section{IMPLICATIONS OF ISLAMIC WORLDVIEW FOR HUMAN RIGHTS AND LEGAL EDUCATION IN TWENTY-FIRST CENTURY AFRICA}

Against the backdrop of labels such as "Muslim terrorists" and "Islamic fundamentalism", it is sometimes an uphill task to advocate a balanced appreciation and understanding of Islamic law. As John Strawson argues:

"Islamic Law has been represented within Anglo-American scholarship as an
essentially defective legal system. The terrain of the critique has changed
from the defence of colonial rule during the age of imperialism to
contemporary claims about human rights, democracy and pluralism. The
problem with this critique is that it replicates the power relationship between
Europe (and the United States) and the Islamic world. The argument that
Islamic Law is defective nourishes the perception that European law is
complete. As a consequence, a genuine engagement with Islamic Law
becomes problematic as every encounter is drawn onto the terrain of the
orientalist narrative. A critique which is based on superiority and political
power, rather than on scientific enquiry, must be flawed. Given the importance
of the Islamic world in general...to international peace, this flawed critique
merely adds one more obstacle to meaningful discourse and debate.".

An Islamic legal scholar had argued that previously, Islamic juristic thought had been preoccupied with ensuring conformity to the letter of the divine text, a paradigm which presented the Sharia as a set of rules, commands and prohibitions meant for individuals who are expected to conform to its directives. ${ }^{59}$ Subsequently, the formulation of the theory of benefits (maqasid) stressed that the Sharia is rational, goal-oriented and generally founded on identifiable causes. Thus, a mere conformity to rules that went against the purpose and outlook of the Sharia was generally considered unacceptable. ${ }^{60}$

With regard to human rights, Islamic law defines its own universal principles, as we have seen above. In comparison to Western standards, however, it has been said that Islamic law falls short of the protection provided by international human rights, for example, those enshrined in the Universal Declaration of Human Rights (UDHR), $1948 .{ }^{61}$ In another context, it has been argued that contemporary endorsement of international human rights by Muslims is more apparent than real, because all human rights pronouncements by Muslim individuals and groups have been curtailed by

58 Strawson "Encountering Islamic Law" <http://www.uel.ac.uk/faculties/socsci/law/jsrps.html> (accessed 2010-02-14).

59 Kamali "Maqasid Al-Shari'ah: The Objectives of Islamic Law" 1999 2(38) Islamic Studies 195198.

$60 \mathrm{Ibid}$; and see also Safi "Human Rights and Islamic Legal Reform" International Islamic University Malaysia <http://www2.iiu.edu.my/deed/articles/html> (accessed 2010-02-14).

61 Safi in fn 60 above. 
qualifications rooted in the Sharia. ${ }^{62}$ The main thrust of argument against the reconciliation of Islamic law with international human rights principles is that the application of Islamic law leads to serious breaches of international human rights norms and, specifically, its application erodes religious freedom and discriminates against women and non-Muslims. ${ }^{63}$

Having dealt with many of the intellectual misconceptions about Islam and Islamic law in the preceding segment, it suffices here to examine those critical factors that make the interjection of Islamic juristic thought in the teaching of human rights law a sine qua non to the making of an African lawyer well-equipped for the challenges of the twenty-first century.

As earlier highlighted, for African countries, the weaknesses in law teaching in Africa and the consequent adverse effects on curriculum and pedagogy make the studying and understanding of Islamic law to be of critical importance. Further, with the inevitable wind of globalization across the world, the quest for the "globalized", socially relevant and "complete" lawyer as well as for all-inclusive human rights education makes it inevitable for African law schools to engage Islamic law in the delivery of legal training programmes.

Beyond the above factors, it is also of importance that the incorporation of Islamic law precepts, particularly those relating to the protection of the dignity of the human person, be placed on the front burner of legal education in Africa in the present century in which the continent is plagued by the scourge of revived nationalism, religious fundamentalism, xenophobia, intrastate conflicts, legal and illegal human migrations, unending refugee crisis, and the struggle for identity. ${ }^{64}$ If the precept holds true that the language of the global human rights movement in the 21 st century is universality, ${ }^{65}$ then it will be out of place for the training of African lawyers to manifest the exclusion of ideas in any form. Every prospective lawyer needs at least to know basic Islamic law principles.

After all, Islamic law is applicable to vast African peoples, even where it is not generally applicable to entire national populations. A legal practitioner will inevitably encounter legal problems that relate to Islamic law from time to time. The substantial advances in Islamic banking as seen in Nigeria and South Africa have the potential of opening up new career opportunities for

62 Ibid; and see Mayer Islam and Human Right: Tradition and Practice 2ed (1995).

63 See Howard Human Rights and the Search for Community (1995); and An-Na'im in fn 32 above.

64 For insight into some of these subjects of critical concern to Africa, see Oladipo Remaking Africa: Challenges of the Twenty-First Century (1998); Legal Defence and Assistance Project (LEDAP) Legal Protection of Human Rights in Africa: Problems and Challenges (1999); Gerwel "Foreword" 2000 1(2) African Journal of Conflict Resolution 7-9; and Olowu "Refugees, Asylum-Seekers and the Legal Obligations of States for Their Protection: Critical Reflections on the South African Approach" 20066 ISIL Yearbook on International Humanitarian \& Refugee Law 233.

65 On this point, see Shelton "Protecting Human Rights in a Globalised World" 200225 Boston College International \& Comparative Law Review 273; Donnelly Universal Human Rights in Theory and Practice 2ed (2003); and Park "Correlates of Human Rights: Global Tendencies" 19879 Human Rights Quarterly 405. 
law graduates. Thus, law schools will increasingly have to offer Islamic law modules to remain competitive and relevant. ${ }^{66}$

Further, judges and court officials also need to know basic Islamic law as they will have cause to rule on matters of Islamic law. In countries where Islamic law is administered in the same court system as civil, common or Roman-Dutch law, knowledge and skill of Islamic law tenets will be a prerequisite for optimum performance. In other countries where Islamic Law is administered through a separate judicial system, it may seem that acquaintance with Islamic law is essential only for those who administer the Islamic system. However, this may not be wholly true because in some jurisdictions like Burkina-Faso, Chad, Niger, Nigeria, and Senegal, although most Islamic law matters would go to specialized Sharia courts, there will always be matters requiring some knowledge of Islamic Law, which may be outside Muslim personal laws, that usually fall within the jurisdiction of the civil court. ${ }^{67}$

In many African countries, including South Africa, matters implicating Islamic law in transactions continue to be tried by civil courts because no Sharia court system exists having jurisdiction in these matters. ${ }^{68}$

Rather than vilifying Islamic law as old-fashioned, therefore, its precepts indeed commend themselves for the interrogation of international human rights jurisprudence in the present age. African human rights lawyers and scholars have got a wealth of insight to discover in Islamic law. This truism is as critical to human rights lawyers and scholars in Africa as elsewhere.

What should be the bottom-line for the integrative human rights law teacher is the ability to understand Islamic human rights thought from its own religious perspective, principles and traditions and not from purely Western points of view. After all, Islamic law has had a long history of engaging international law principles. ${ }^{69}$

\section{MAINSTREAMING ISLAMIC JURISTIC THOUGHT IN HUMAN RIGHTS EDUCATION IN AFRICAN LAW SCHOOLS: STRATEGIES FOR INTEGRATIVE CURRICULUM AND PEDAGOGY}

Since 1948, when the Universal Declaration of Human Rights was adopted, the international community has placed the dissemination of human rights squarely on global policy agenda as evident in diverse initiatives,

66 Bari "Legal Education and Islamization" 19997 International Islamic University Law Journal 83.

67 Ibid.

68 One of the tangential cases on this point was Islamic Unity Convention $v$ Minister of Telecommunications, CCT33/07, concerning the investigation and adjudication of complaints lodged with the Independent Communications Authority of South Africa (ICASA) against holders of broadcasting licences.

69 See in this regard, Khadduri The Islamic Law of Nations, Shaybani's Siyar (1966); Weeramantry Islamic Jurisprudence: An International Perspective (1988) 149-150; and Strawson in fn 58 above. 
programmes and instruments. Prominent among these were the Principles of the International Congress on the Teaching of Human Rights, 1978; the Malta Recommendations on Human Rights Teaching, Information and Documentation, 1987; the World Plan of Action on Education for Human Rights and Democracy, 1993; the Vienna Declaration and Programme of Action, 1993; United Nations Decade for Human Rights Education, 19952004; the Guidelines for National Plans of Action for Human Rights Education, 1997; and the Dakar Framework for Action, 2000. ${ }^{70}$ These initiatives have been complemented by similar programmes across regional and national frontiers, most remarkable among which is the Windhoek Declaration on Principles and Guidelines for Teaching Law in African Law Faculties, and Other Legal Education Institutions, adopted in March 2008.

Despite all these elaborate initiatives aimed at the ultimate goal of establishing a sustainable culture of respect for human rights through education, however, there remains the general challenge of identifying viable pedagogical approaches towards the realization of this goal. ${ }^{71}$ Interestingly, the challenge of appropriate human rights pedagogy confronts educators and scholars in institutions of legal education across diverse geo-political regions of the world: as problematic for educators in the Western world as it has been for their counterparts in the so-called Third World. ${ }^{72}$

While the teaching of human rights encompasses the broader contexts of formal and informal education - for democracy activists, legal practitioners, judges, magistrates, prison administrators, police officers, prosecutors, ombudsmen, immigration workers, non-skilled workers and the like - our primary focus of at this juncture is the pedagogical challenge encountered in the teaching of human rights vis-à-vis Islamic law as a distinct or integral part of substantive subjects within a legal education curriculum. Even though Addo and Rembe had individually raised concerns about Africa's challenges with the global agenda for human rights education, ${ }^{73}$ they both omitted the gaping lacuna in the approaches to curriculum and pedagogy in the teaching of the subject in African law schools.

70 See generally Olowu "Teaching Human Rights Law in a Multicultural Regional University: A Reflective Experience in Pedagogy" 2004 26(2) Directions: Journal of Educational Studies 13.

71 See generally Addo "Implementation by African States of the Plan of Action for the United Nations Decade for Human Rights" 2000 44(1) Journal of African Law 96; Rosenblum "Teaching Human Rights: Ambivalent Activism, Multiple Discourses, and Lingering Dilemmas" 200215 Harvard Human Rights Journal 301 302-304; and Rembe "To Reaffirm Faith in Fundamental Human Rights: The Challenge of Managing Diversity in Africa" 2002 17 Connecticut Journal of International Law 303304.

72 Scheinin "Experiences of Teaching Human Rights with Law Students and Professional Target Groups" in Åkermark (ed) Human Rights Education: Achievement and Challenges (1998) 47-52; and Steiner "The University's Critical Role in the Human Rights Movement" 200215 Harvard Human Rights Journal 317.

73 Addo 2000 44(1) Journal of African Law 99-101; Rembe 200217 Connecticut Journal of International Law 305-307. 
Unlike other subjects which can be taught at a theoretical level, human rights education should be administered through cognitive principles. ${ }^{74}$ As such, the teaching of human rights should be seen as an effort to improve the environment of teaching and learning in the conventional classroom. I contend that in this age of increased globalization, purposeful human rights education must emphasize the need for the student to be conscious of the proximity of, and sometimes, the inevitable nexus between broader human rights issues and local/personal concerns. To this end, an integrative human rights module should reflect Islamic law ideas in the four critical areas of (i) content, (ii) learning objectives, (iii) teaching methods and (iv) evaluation techniques, in accordance with universally recognized principles of teaching in higher education. ${ }^{75}$

Of course, effective human rights education cannot merely be about understanding the integrative principles at the cognitive level but should also be oriented to shift the attitude of the students to be responsive to any form of human rights violations, anywhere. Moreover, law students should be encouraged to develop a balanced attitude between rights and responsibilities in their social life. The appropriate method to deliver human rights education is interactive learning, as it requires the lecturers to become facilitators capable of monitoring the level of students' comprehensive understanding about human rights principles and help to raise it to a higher level.

It is therefore critical to bear in mind that human rights consciousness is determined by students' thinking, beliefs, feelings, habits and attitudes. Through the integration of Islamic law principles into the human rights curriculum, law teachers should be encouraged to develop learning objectives which allowed the students to achieve the third level of learning competence which is the ability to live in a pluralistic society.

There will certainly be impediments to the realisation of the goal of integrative human rights education in African law schools. For one, there has been a lot of misunderstanding of and prejudice against Islam and Islamic law which must be removed through painstaking advocacy.

Another factor would be the scarcity of human rights academics who have mastered both the Islamic and Western aspects of human rights law. They are a rare species in Africa. It is reasonable to project that with more positive attitudes from university authorities in Africa, upcoming legal scholars would emerge who are committed to the goal of making the teaching of human rights law truly universal and integrative.

In developing a rapid agenda towards integrative human rights law curriculum and pedagogy, one starting point would be for individual law

74 According to Angelo, this principle relates to that used by cognitive psychologists to describe students' awareness and understanding of their own learning skills, performance and habits. It implies two different but related aspects: (i) awareness and knowledge of self as learner and (ii) conscious self-control and self-regulation of cognition. See Angelo and Cross From Classroom Assessment Techniques, A Handbook for College Teachers 2ed (1993) 255.

75 See generally Lovell-Troy and Eickmann Course Design for College Teachers (1992). 
schools to adopt a policy that would ensure that every research thesis and course syllabus on human rights reflects the Islamic law dimension of the subject-matter. Conversely, in universities that have traditionally been ardent in the teaching of Islamic Law almost exclusively, a similar policy should be adopted that would ensure that every research thesis and course syllabus on human rights reflects the Western dimension of the subject-matter. I conjecture that by so doing, the scarcity of resources on Islamic jurisprudence in languages other than Arabic would diminish in course of time. The professionalization of human rights law education could also create a group of scholars and practitioners whose competence would be recognized anywhere in the world. ${ }^{76}$ The lack of references on Islam and human rights issues should be overcome by encouraging the academic staff in African law schools to pursue contextually relevant human rights research. The translation of some outstanding classical works on Islamic perspectives to human rights issues is essential in order to accommodate the academic staff and the students who have language barriers. If African legal educators attend carefully to accepted standards for teaching about human rights, more authentic and less confusing accounts will result. African law textbook authors should thus write about Islam and all other faiths not to persuade belief or disbelief, but to record as precisely as possible both the findings of contemporary scholarship and the understandings that Muslims have of human rights.

In order to integrate Islamic juristic thought principles fully into the teaching of human rights law modules in Africa, workshops should be conducted for all the academic staff in respective African law schools. The feedback expressed by participants at such workshops should be taken into account in designing future workshops. The initiative to raise sensitivity towards human rights violations under any guise in the African region should be tolerated. This idea is necessary to build a strong base in enabling human rights law teachers to integrate the principles into their teachings and to stimulate behavioural changes.

The learning impact of the integration project should also be assessed through the students' points of view as well as their learning outcomes. The assessment will eventually give feedback to the teaching staff in improving their teaching competence.

Similarly, establishing a Pan-African resource centre on Islamic Law and human rights will not be out of place in addressing many of the challenges and tasks identified in this article. The Association of African Universities should be the vanguard of this initiative.

76 See Dzuhayatin 20052 Muslim World Journal of Human Rights 14; and Oba "Islam, the West and Human Rights: Towards Reconciling the Divergences" Paper presented at the International Conference on Harmonization of Sharia and Civil Law, International Islamic University Malaysia, Kuala Lumpur, 29-30 June 2005. 


\section{$7 \quad$ CONCLUSIONS}

For a long time, human rights issues in international relations were conceived as pertaining only to Western civilizations. This article has contended that this conception is erroneous. Debates on the nature of the Sharia in Islamic countries and elsewhere have been of tremendous intellectual interest, but they fail to advance the cause of international human rights.

In today's world, people understand the importance of the respect for the dignity and distinctiveness of every human being. Similarly, there is a consciousness of dignity trampled upon in various human societies. There are many reasons, however, for us to consider the issue of human rights as of strategic consequence. This article proceeded on the premise that the human dignity of every human being can be appropriately affirmed and given effective protection only within the framework of an interrelated system of norms, principles and institutions.

One lesson of the Cold War in this regard is that only a firm and noncompromising stand regarding the most fundamental questions can lead to the effective implementation of the ideals and objectives of international human rights everywhere. Africa certainly has a stake in integrating Islamic juristic thought into all human rights discourses on the continent.

While acknowledging that for too long Islamic law has largely been relegated in much of African law schools, I have made an attempt at accentuating the inevitable necessity for lawyers in Africa to be well trained in inclusive and integrative ways. Training prospective African lawyers in human rights law and practice without appropriate consideration of the Islamic perspective to human rights precepts amounts to playing ostrich with a phenomenon that could short-change the continent in human capital formation and social progress which are in dire need.

Far from being an ex cathedra pronouncement on all the dynamics that would inform the progressive integration of Islamic juristic thought into the conceptualization and delivery of human rights education in African law schools, this article would have served its purpose if it stimulates further scholarly discussions on its theme. 